\title{
The economics of disaster relief
}

Citation for published version (APA):

Dari-Mattiacci, G., \& Faure, M. G. (2015). The economics of disaster relief. Law and Policy, 37(3), 180208. https://doi.org/10.1111/lapo.12036

Document status and date:

Published: 01/07/2015

DOI:

10.1111/lapo.12036

Document Version:

Publisher's PDF, also known as Version of record

Document license:

Taverne

Please check the document version of this publication:

- A submitted manuscript is the version of the article upon submission and before peer-review. There can be important differences between the submitted version and the official published version of record.

People interested in the research are advised to contact the author for the final version of the publication, or visit the DOI to the publisher's website.

- The final author version and the galley proof are versions of the publication after peer review.

- The final published version features the final layout of the paper including the volume, issue and page numbers.

Link to publication

\footnotetext{
General rights rights.

- You may freely distribute the URL identifying the publication in the public portal. please follow below link for the End User Agreement:

www.umlib.nl/taverne-license

Take down policy

If you believe that this document breaches copyright please contact us at:

repository@maastrichtuniversity.nl

providing details and we will investigate your claim.
}

Copyright and moral rights for the publications made accessible in the public portal are retained by the authors and/or other copyright owners and it is a condition of accessing publications that users recognise and abide by the legal requirements associated with these

- Users may download and print one copy of any publication from the public portal for the purpose of private study or research.

- You may not further distribute the material or use it for any profit-making activity or commercial gain

If the publication is distributed under the terms of Article $25 \mathrm{fa}$ of the Dutch Copyright Act, indicated by the "Taverne" license above, 


\title{
The Economics of Disaster Relief
}

\author{
GIUSEPPE DARI-MATTIACCI and MICHAEL G. FAURE
}

\begin{abstract}
We distinguish among three types of actions that can be taken to alleviate the consequences of natural disasters: precautionary efforts (made ex ante), relief efforts (made in the immediate aftermath of a disaster), and recovery efforts (made ex post). We argue that recognizing this distinction lessens many of the problems that the literature attributes to government intervention and hence expands the scope of government action following disasters. Relief is less likely than recovery to generate over-supply by the government and over-reliance by victims.
\end{abstract}

\section{INTRODUCTION}

Government intervention in relation to catastrophic events has a poor reputation. It is criticized in the literature for being excessive ex post and insufficient ex ante. Often, ex post intervention could be efficiently substituted by cheaper measures taken before the disaster. For instance, prior to hurricane Katrina there was a lack of investment in Louisiana's levee systems, inadequate zoning regulations, and an absence of emergency planning (Houck 2006; Waugh 2005), but various government authorities "participated in the race to provide relief" ex post, with costs of over $\$ 100$ million (Depoorter 2006, 112). The same story can be told of hurricane Irene, which, a few years later, destroyed homes, businesses, and roads, and caused over $\$ 15$ billion in damage. The flood had these disastrous effects because of unregulated human activities, such as the armoring of the rivers, the hardening of flood plains, and the development of watersheds (Pidot 2012).

Yet government intervention is crucial, not only to alleviate the immediate consequences of disasters, but also to reduce their long-term effects (Noy 2009). Thus, understanding the causes for the failure of government

G. Dari-Mattiacci gratefully acknowledges financial support from the Netherlands Organization for Scientific Research (NWO VIDI grant 016.075.332). The authors would like to thank the editor Nancy Reichman, three anonymous referees, Mergherita Saraceno, Avi Tabbach, and Josephine van Zeben for valuable comments, and Liu Jing, Liao Wenqing, Andrea Rigamonti, and Wang Hui (Maastricht) for valuable research assistance.

Address correspondence to Giuseppe Dari-Mattiacci, Amsterdam Center for Law and Economics, University of Amsterdam, Plantage Muidergracht 12, 1018 TV, Amsterdam, the Netherlands. Telephone: +31 20525 7157; Email: gdarimat@uva.nl. 
intervention is crucial to better disaster management. The evidence points to politics and strategic reactions to the prospect of disasters as the sources of the above-mentioned problems. Politicians usually have short time horizons and tend to avoid thinking about low-probability events until they occur (Kunreuther 2010a). Precautionary expenditures generate immediate costs and thus put pressure on the public budget while producing gains only if a disaster materializes, that is, in a very small percentage of the cases. Moreover, a disaster that causes little damage is likely to go largely unnoticed, thereby further reducing the political gains of precautionary efforts; invisible and improbable gains are traded against conspicuous and sure costs (Depoorter 2006). Ex post intervention, instead, provides a salient occasion for political visibility and is likely to be used as a stage for political campaigns. Because recovery efforts are very visible, political entities will compete to provide them, leading to excessive expenditures ex post. There are high political (electoral) rewards attached to ex post intervention, and recent evidence shows a correlation between elections and realized ex post expenditures; disasters occurring in election years attract more ex post funding relative to disasters in other years (Michel-Kerjan 2010). Research has also shown that, in the United States, the Federal Emergency Management Agency's (FEMA) disaster expenditures are higher in states that have congressional representation on FEMA oversight committees. Half of all disaster relief, the research shows, is motivated by politics rather than altruism (Garrett, Marsh, and Marshall 2006; Garrett and Sobel 2003). In addition, popular beliefs and news coverage tend to overstate the risk of looting, anarchy, and violence in disaster areas. Therefore, politically motivated intervention might put too much weight on these news-sensitive problems and hence divert resources away from humanitarian intervention (Sun 2011a).

Leveraging this criticism, law and economics scholars have forcefully argued against ex post government intervention (see, among many others, Epstein 1996; Kaplow 1991). The point that we develop in this article is that the arguments made in the literature against government intervention hold for recovery (compensation) but not for immediate disaster relief. Thus, we aim to carve out a broader scope for government intervention than that advanced in extant analyses. We first argue that a distinction should be made between three classes of activities involved in disaster management: precaution, relief, and recovery. Precautionary efforts are made ex ante (at time -1), often months or even years before a disaster strikes; relief efforts are made in the immediate aftermath of a disaster (at time 0 ); and recovery efforts are made ex post (at time +1 ), after the disaster, and are intended to return conditions to those that prevailed ex ante. A somewhat similar distinction is made by Mileti (1999) among preparedness, response, and recovery.

We argue that there are strong reasons for immediate, ad hoc disaster relief by the government. The need for rapid action, combined with economies of scale and the public good character of immediate disaster relief, increases the scope for government intervention and mitigates the inefficiencies, noted 
above, which affect recovery efforts. Although there might be political incentives to oversupply relief and incentives for victims to over-rely on ex post government intervention, relief reduces the social cost of disasters. Thus, expenditures on relief save precautionary and recovery costs. In contrast, recovery only shifts the costs of disasters from victims to government agencies and hence does not affect the optimal investments in precaution and relief. This fundamental difference between relief and recovery drives our analysis.

In Part II, we review the literature against ex post government intervention and show that it does not generally distinguish between relief and recovery, a distinction that we introduce in Part III. In Part IV, we examine this distinction against the available evidence, which points to major expenditures in relief rather than recovery, supporting our claim that government intervention might be less undesirable than it seems. In Part V, we present a formal model explaining the interdependencies between precaution, relief, and recovery. In Part VI, we draw some lessons from the model and discuss the different effects of recovery and relief. Part VII defines a notion of optimal relief and Part VIII concludes.

\section{EX POST GOVERNMENT INTERVENTION AND ITS CRITICS}

Certain law and economics scholars have strongly argued against ex post government intervention after disasters. Epstein (1996) has called this type of ex post compensation "catastrophic responses to catastrophic risk," and Gollier $(2005,25)$ has argued that "solidarity kills market insurance" (see also Raschky and Weck-Hannemann 2007; Priest 1996). There is empirical evidence regarding the effects of disaster relief on the demand for crop insurance, showing that producers' beliefs about the availability of disaster relief has a significant negative impact on their willingness to purchase insurance (Trebilcock and Daniels 2006; Van Asseldonk, Meuwissen, and Huirne 2002). Accordingly, Kunreuther (1968, 2006, 2010a) has repeatedly and powerfully argued for the introduction of a mandatory comprehensive insurance program.

These effects further reinforce the problem. Helpless, uninsured victims are more vulnerable to disasters and therefore require more ex post aid, which in turn makes the disaster more salient and politicians more eager to stage a rescue. This negative spiral results in a less-safe environment and higher death tolls (Pidot 2012). There are some (isolated) voices who call for different solutions (see, for instance, Farber 2007). Among them, Van Langendonck (2007) has argued that the government should provide social insurance for natural disasters, whereby compensation for disasters would be provided in the same way as social security is provisioned. However, when he discusses the scope of social insurance, he essentially refers to immediate help through a specialized task force (compensating local authorities for the cost 
of emergency intervention) rather than long-term reconstruction efforts (refunding local authorities for the cost of compensation payments to victims for personal damage). He explicitly argues that it is unadvisable that such a fund should be used to compensate individuals or enterprises for losses related to private property damage.

The problem, as powerfully shown by Viscusi (2010), is that following a major disaster, society (and thus politicians) suffers from a hold-up problem. It is simply politically impossible to deny assistance "once there are identified victims and their stories are featured on the evening news" (ibid., 146). In other words, the (political) pressure to provide relief to victims ex post is very strong and leads to the so-called Samaritan's dilemma: the government grants ex post compensation, even if this is likely to have negative ex ante effects on incentives (Coate 1995). This problem is also referred to as charity hazard, and scholars have argued that the main advantage of insurancebased solutions is that they can provide incentives to invest in hazard mitigation (Kunreuther, Michel-Kerjan, and Ranger 2013; Kleindorfer, Kunreuther, and Ou-Yang 2012). The same authors also propose to restructure the United States' National Flood Insurance Program (NFIP) to provide better incentives for hazard mitigation. Kousky and Kunreuther (2013) also criticize the current NFIP for addressing insurance affordability through discounted premiums. They instead propose a means-tested insurance voucher program, coupled with a loan program for investments in hazard mitigation.

A mandatory comprehensive disaster insurance model has existed in France since 1987 and, although there are criticisms of its specific institutional design (see Van den Bergh and Faure 2006), there is general support for the French model, which is not only receiving increased attention in scholarship, but has also been recently introduced in Belgium and is under consideration in other countries (Bruggeman, Faure, and Haritz 2011; Bruggeman 2010). Politicians, however, often oppose the introduction of mandatory insurance as larger political gains can be obtained through ad hoc measures after a disaster. (For a comparative analysis of various European systems, see Schwarze, Schwindt, Wagner, and Weck-Hannemann 2012; see also Paudel 2012.)

\section{DEFINITIONS: PRECAUTION, RELIEF, AND RECOVERY}

We propose a distinction between three classes of activities that bear on the magnitude and probability of losses related to disasters. Before elaborating on our distinction, note that there is a difference between technological, man-made disasters and natural catastrophes. Examples of technological disasters are oil spills, nuclear accidents, explosions in particular plants, or fire in a public building. Natural catastrophes include heavy rainfall, floods, earthquakes, volcanic eruptions, tsunamis, and many others (Faure 2013). 


\begin{tabular}{c|c|c} 
Ex ante & Disaster & Ex post \\
\hline Time -1 & Time 0 & Time +1 \\
Precaution & Relief & Recovery
\end{tabular}

Figure 1. Three Types of Disaster Efforts.

We mainly focus on natural disasters. The reason is that considering manmade disasters would introduce concerns as to the optimal mix of victims' and tortfeasors' precaution, which complicates the analysis without affecting our main point. Our observations about the differences between relief and recovery also apply to man-made disasters.

We distinguish between precautionary efforts (made ex ante, at time -1 , such as building dikes), relief efforts (made in the immediate aftermath of a disaster, at time 0 , such as providing shelter, food, and medical assistance to victims), and recovery efforts (made ex post, at time +1 , such as funds for reconstructing homes and infrastructure). Figure 1 offers a graphical representation of these categories, and the following sections expand on them (for a recent bipartite taxonomy and analysis of ex ante versus ex post policy tools, see Iacobucci, Trebilcock, and Haider 2001).

\section{A. PRECAUTION}

Precautionary efforts encompass all those actions that can be taken ex ante in order to prevent an event from happening, reduce its probability, or mitigate the seriousness of its consequences (Leonard and Howitt 2010). Precautionary efforts can be taken by the government or, depending upon the scale, by individuals. For example, property owners in flood-prone regions can elevate their houses, and people living in earthquake-prone regions can bolt the structures of various installations to the foundation of their homes (Kunreuther 2010b). It has been stressed by O'Keefe, Westgate, and Wisner (1976) that many disasters can be prevented and that a lack of precautionary measures is often the real reason why natural events have catastrophic consequences. Yet, when the scale of the measures needed is sufficiently large, precautionary efforts are more efficiently undertaken by the government. For example, governments can build levees to prevent flooding and structures to protect coasts from tsunamis, and can introduce earthquake-warning systems (Zeckhauser 1996, 134). An important task of the government is the issuance of zoning regulations-for example, prohibiting constructions in flood-prone areas or prescribing particular building techniques in areas prone to earthquakes (Sun 2011b; Ellickson 1973). As Trebilcock and Daniels $(2006,91-92)$ note:

In the case of hurricanes, a number of important potential precautionary strategies that are designed to minimize the expected costs or consequences associated with a natural disaster (but not the risk of its occurrence which we 
are assuming to be exogenous) have many of the characteristics of public goods and if left purely to private markets are likely to be under-demanded and under-supplied as a result of collective action problems.

For example, in the case of Katrina, Shughart (2006) shows that no effective precautionary measures were taken before Katrina was announced because of bureaucratic myopia, bureaucratic inertia, and corruption. With respect to particular disasters, such as a terrorist attack, the argument is made that little can be expected from civilians in terms of preventive measures. The goal of a terrorist attack is often to disrupt society. Terrorists may adopt strategies to which governments can potentially react more effectively than individuals. Governments may also have more information about ongoing terrorist groups' activities, through intelligence services (Kunreuther and Michel-Kerjan 2005). The same is true of large-scale infrastructure projects, needed to prevent catastrophes (e.g., building dikes to defend against tsunamis). These are public goods that would not be provided through private action and may thus require government intervention.

Individuals can limit their exposure to risk primarily by optimizing their location and through other, similar decisions. Examples of the latter include not placing valuables in basements vulnerable to flooding or, in earthquakeprone areas, choosing a type of construction not highly vulnerable to earthquakes. ${ }^{1}$ A problem with some precautionary actions is that they may not fully prevent damage while creating an illusion of complete safety. For instance, the construction of levees reduces the probability of flooding, but by inducing settlement in flood-prone areas, the construction may increase the magnitude of harm, should a flood occur (Mileti 1999). In our analysis, we focus exclusively on victims' precaution. However, all of our arguments also apply to cases where it is efficient that the government takes precaution. As will be clear from the analysis, our argument is weaker when victims' precaution is efficient and hence applies a fortiori to cases of government precaution, where the dilution of incentives due to relief is less serious. ${ }^{2}$

\section{B. RELIEF}

Relief effort consists of executing an effective, damage-limiting response immediately after an event. For example, in the United States, federal relief efforts consist of "coordinating necessary decisions, support[ing] search and rescue efforts, and [. . .] provid[ing] public health, medical and mental health support at casualty evacuation points and refugee shelters" (Report: Disaster Evacuation, 2-3). As Sugarman (2007, 32) notes, "[i]n the immediate aftermath of a hurricane, for example, people may need basic temporary shelter; then they may need transitional housing while they are finding a new place to settle or their former homes are cleaned up, fixed and/or rebuilt; and they may need help with those processes."

Because disasters usually strike unannounced, relief requires a rapid coordinated effort, the pooling of significant resources and manpower, and the 
mobilization of communications and medical infrastructures. In addition, when a population is evacuated, it is necessary to provide policing against looting and outbreaks of violence. The problem, however, is not only logistics or funding. Rather, these activities often require special legal means that only a local or central government body can provide. Such means include control of police and military forces deployed in affected areas; the ability to communicate effectively with the population; the imposition of restrictions with respect to access to, or exit from, particular areas; and the power to seize or expropriate private property.

\section{RECOVERY}

Recovery effort is ex post intervention needed to return the social welfare trajectory to where it would have been had the disaster never occurred (Leonard and Howitt 2010). Recovery consists of two kinds of effort: reconstruction activities and victim compensation. Reconstruction activities are typically aimed at restoring public services and the country's infrastructure such as roads, harbors, or railways. Examples of victim compensation include government payments, which go beyond immediate relief, to victims of disasters. These payments are usually not merely aimed at the provision of public health (medical and mental health support at the moment of the disaster), but also occur at a later stage. They are usually intended to compensate people for property loss and, in some cases, are organized in a structured way-for example, in Belgium (Durant 2006) and Austria (Hinghofer-Szalskay and Koch 2006) - via a publicly financed disaster compensation fund that pays (limited) amounts of compensation to disaster victims. However, the most common way of compensating disaster victims (as part of recovery efforts) is on an ad hoc basis.

This type of recovery effort is often, but not exclusively, inspired by political motives and can be found on both sides of the Atlantic. In Europe, such payments took place in Germany after the Elbe flooding of 2002, where $€ 8.1$ billion were made available to victims of flooding (Magnus 2006). In Italy, on average $€ 3.5-4$ billion per year are spent to indemnify victims of damage caused by catastrophic events (Monti and Chiaves 2006). In the United States, after Katrina, as of February 2006, " $\$ 88$ billion in federal aid had been allocated for relief, recovery and rebuilding, with another $\$ 20$ billion requested to help victims of the storm and to rebuild the region" (Report: Progress Made). Additionally, in Japan, generous support funds, reconstruction funds, and financial aid for disaster victims (especially of earthquakes) exist, and following the recent Fukushima incident of March 2011, a corporation was created to compensate victims (Faure and Liu 2012). To ensure full compensation, the Japanese government has decided to issue government bonds of 2 trillion yen ( $\$ 26$ billion) to help the operator TEPCO (Tokyo Electric Power Company) pay compensation and is considering approving a supplementary budget of 3 trillion yen ( $\$ 38$ billion; Faure and Liu 2012). 
Largely, recovery expenditures simply shift the costs of the disaster from victims to government agencies. At the recovery stage, it is typically too late to reduce the costs of an accident; the question is only who pays for them. As mentioned, we focus on cases in which victims' precaution is efficient, and, hence, government recovery is undesirable because it reduces victims' incentives. Yet, our results are not based on this assumption, and they remain valid in cases of government precaution. The reason is that the differences between relief and recovery that we identify do not depend on who should pay for recovery.

\section{RELIEF VERSUS RECOVERY IN RECENT NATURAL DISASTERS}

We will now discuss the spending in the aftermath of particular recent disasters in order to examine the relative amounts of spending for relief versus recovery. Obviously, there are some difficulties in this respect since data are often lacking or contradictory. It is also not always possible to provide sharp distinctions between relief and recovery, and for recent disasters (like Fukushima) the final amounts are not known yet. Notwithstanding these caveats, the data on a few recent disasters shed light on the central point of our article.

\section{A. KATRINA}

Katrina made landfall near the Louisiana-Mississippi border on the morning of August 29, 2005, and would become the most expensive natural disaster in US history, and also one of the deadliest (Report: A Failure of Initiative 7). Total costs of Katrina were (as of February 2006) estimated to be $\$ 96$ billion. 300,000 homes were destroyed or uninhabitable and 1,330 people died. That made Katrina far more expensive than the terrorist attacks on 9/11, whose total estimated damage was valued at $\$ 18$ billion (Report: Lessons Learned 7,211).

Relief to the victims could be provided via the local authorities on the basis of the Stafford Act. An individual or household could receive a maximum of $\$ 26,200$ of Individual and Household Program (IHP) assistance through FEMA, financed by a cost sharing between the federal government and the state. The Stafford Act determines the federal assistance as well as the financial assistance provided by FEMA, which can include direct payments, grants, loans, and insurance. Funding is capped at $\$ 5$ million. In case of an emergency declaration when the president has declared an event a major disaster, no financial limit applies, and states can request federal assistance (Report: Performance Review 13, 16-17; Report: Lessons Learned 18). In the bipartisan committee report $A$ Failure of Initiative, an amount of $\$ 63$ billion was held to be allocated to "disaster relief." By November 30, 2005, \$19.3 
billion had been paid "to relieve the immediate suffering of individuals and families, clear debris, reimburse federal agencies for the costs of technical and direct assistance, and support federal operations such as search and rescue and delivery of consumables" (Report: A Failure of Initiative 310). The report shows that the money went, inter alia, to personal needs that were not met by insurance and temporary housing (including vouchers for hotel/ motel rooms and mobile homes), debris removal, damage inspections, hazard mitigation, etc. A later Senate report refers to a total amount of $\$ 88$ billion that the federal government had committed as of March 8, 2006 "to the response, recovery and rebuilding efforts" (Report: A Nation still Unprepared 112).

Interestingly, many of the different reports issued after Katrina point to serious underinvestments in preparedness, particularly by public authorities (both FEMA and state authorities; reports on desirable precautionary efforts by individuals that were not taken are not available). For example, A Failure of Initiative reports that FEMA sustained losses of $\$ 80$ million and $\$ 90$ million in fiscal years 2003 and 2004, respectively, and that "these budget reductions were preventing FEMA officials from maintaining adequate levels of trained and ready staff" (Report: A Failure of Initiative 156). Similar data come from the report by the Department of Homeland Security reporting, inter alia, that between 1995 and 2003, FEMA's budget decreased to such an extent that it was left "unable to conduct a large scale catastrophic event exercise" (Report: A Performance Review 129).

These data on Katrina of course do not provide hard evidence to illustrate our points; the reports do not sufficiently distinguish between relief and recovery. However, when looking at the detailed items for which the emergency payments were made, one notices that a large extent goes to the immediate needs of victims, or to reconstruction by local authorities, and only a limited amount to victim compensation. Many do criticize the way in which FEMA has provided relief and reconstruction, pointing at particular inefficiencies, such as financing reconstruction in the same flood-prone areas, but the amounts awarded for relief were substantially larger than amounts awarded for recovery (if at all). Moreover, the limited information available on precaution seems indeed to underscore the point of underinvestment ex ante and that relief provided by FEMA was not of the perfectly tailored and ready type that we advocate in the analysis.

\section{B. ELBE}

Various studies on the Elbe flood of 2002 also provide information on the amount of losses and their financing (Mechler and Weichselgartner 2003). The official estimate in 2002 was that total losses resulting from the Elbe flooding would amount to approximately $€ 9.2$ billion. Table 1 provides an overview of the losses. 
Table 1. Distribution of the Elbe Flood Losses (December 2002)

\begin{tabular}{lccccc}
\hline $\begin{array}{l}\text { State and Municipal } \\
\text { Infrastructure }\end{array}$ & $\begin{array}{c}\text { Private } \\
\text { Households }\end{array}$ & Business & $\begin{array}{c}\text { Federal } \\
\text { Infrastructure } \\
\text { Incl. Relief Costs }\end{array}$ & $\begin{array}{c}\text { State Relief } \\
\text { and Protection } \\
\text { Costs }\end{array}$ & Agriculture \\
\hline $36.6 \%$ & $28.1 \%$ & $15.9 \%$ & $14.9 \%$ & $2.5 \%$ & $2.1 \%$ \\
\hline
\end{tabular}

Source: Mechler and Weichselgartner $(2003,18)$.

Table 2. Financing Programs in the Elbe Flood

\begin{tabular}{lcccc}
\hline $\begin{array}{l}\text { Emergency } \\
\text { Relief } \\
\text { Financing }\end{array}$ & Private Households & $\begin{array}{c}\text { Residential } \\
\text { Property }\end{array}$ & Business & $\begin{array}{c}\text { Agriculture } \\
\text { and Forestry }\end{array}$ \\
\hline $\begin{array}{c}€ 500 / \text { person, } \\
\text { Max. } € 2,000 / \text { household }\end{array}$ & $€ 5,000 /$ building & $\begin{array}{c}€ 15,000(50 \% \text { of } \\
\text { loss }) \text { and } € 500 \\
\text { /employee }\end{array}$ & $€ 50,000$ \\
\hline
\end{tabular}

\begin{tabular}{lcccc}
\hline $\begin{array}{l}\text { Reconstruction } \\
\begin{array}{l}\text { Financing } \\
\text { Assistance }\end{array}\end{array}$ & $\begin{array}{c}\text { Municipal } \\
\text { Infrastructure }\end{array}$ & $\begin{array}{c}\text { Residential } \\
\text { Property }\end{array}$ & Business & $\begin{array}{c}\text { Agriculture and } \\
\text { Forestry }\end{array}$ \\
\hline $\begin{array}{c}90 \% \text { of } \\
\text { reconstruction } \\
\text { costs }\end{array}$ & $\begin{array}{c}\text { Max. } 80 \% \text { of } \\
\text { reconstruction } \\
\text { costs }\end{array}$ & $\begin{array}{c}35-75 \% \text { of } \\
\text { reconstruction } \\
\text { costs }\end{array}$ & $\begin{array}{c}\text { Max. } 30 \% \text { of } \\
\text { crop losses, } \\
\text { Max. } \\
€ 1 \text { million }\end{array}$ \\
\hline
\end{tabular}

Source: Mechler and Weichselgartner (2003, 31).

Again, apparently large amounts were used for relief, but in this case damage to private households was also considerable. Part of the available compensation (of $€ 9.5$ billion) was used for emergency relief and part for reconstruction as Table 2 shows.

There is no indication, however, of how the precise division between emergency relief and reconstruction took place, although one has the impression that larger amounts were paid in reconstruction than in relief. The Elbe study also provides an interesting tabulation of seven major natural disasters around the world, showing that in fact large parts of the losses (around or over 50 percent) are not compensated at all.

\section{A MODEL OF PRECAUTION, RELIEF, AND RECOVERY}

In this part, we introduce a simple model of precaution, relief, and recovery. The model offers a precise characterization of our notions and of the interactions among them; the results will also be discussed informally in the 
following sections. Modeling a simplified situation has the advantage of allowing us to zero in on the important ingredients of our analysis. When necessary, we offer comments on the effects of variables that are left out of the model, showing that they do not affect the main results.

In the model, there are two actors: a representative victim of a natural disaster and the government. The timing is as in Figure 1. At time -1, the victim sets the level of precaution $p$ that affects the probability of disasters. In the real world, the government can also invest in precautionary effort. We show in the appendix that adding government precaution to the model does not affect the results.

At time 0 , a disaster occurs. Disasters are of two types: there are minor disasters, characterized by $d_{L}$ (low damages), and major disasters, characterized by $d_{H}$ (high damages). Without loss of generality, ${ }^{3}$ we assume that $0<d_{L}$ $<d_{H}<1$. In the aftermath of a disaster, relief effort $r$ can be applied to reduce the magnitude of the damages. We consider two scenarios: one in which the government sets $r$ (at time 0 ) and one in which the victim sets $r$ (at time -1 ).

Finally, at time +1 , the government provides for some recovery by paying a fraction $s$ of the damages. We will first solve the model by using backward induction, hence starting from time +1 , and consider the two relief scenarios separately. Then, we will compare them and draw some general lessons. In particular, we will stress the difference between government intervention in relief at time 0 and government intervention in recovery at time +1 . The mathematical proofs of the various propositions discussed below are provided in the appendix.

\section{A. CASE-SPECIFIC RELIEF EFFORT IS PROVIDED BY THE GOVERNMENT}

We start with the case in which relief effort is provided by the government and is case specific; that is, it is chosen at time 0 after having observed whether damages are high or low. We postulate that the government can do so, due to its greater budget, superior information, and capacity to mobilize resources. Figure 2 depicts the timing of the actions that the parties can take.

\section{Recovery}

At time +1 , after a disaster has occurred, the government pays a portion $0 \leq$ $s \leq 1$ of the damages of major disasters. Nothing is paid for minor disasters. This formulation captures the idea that major disasters attract media attention and are electorally salient. This framework is very general, as $s$ can be set to 0 (the victim pays the full cost) or to 1 (the government picks up the entire bill).

\section{Relief}

At time 0 , relief effort can be exerted in order to reduce the magnitude of the loss. If a minor disaster has occurred, the magnitude of the damages is 


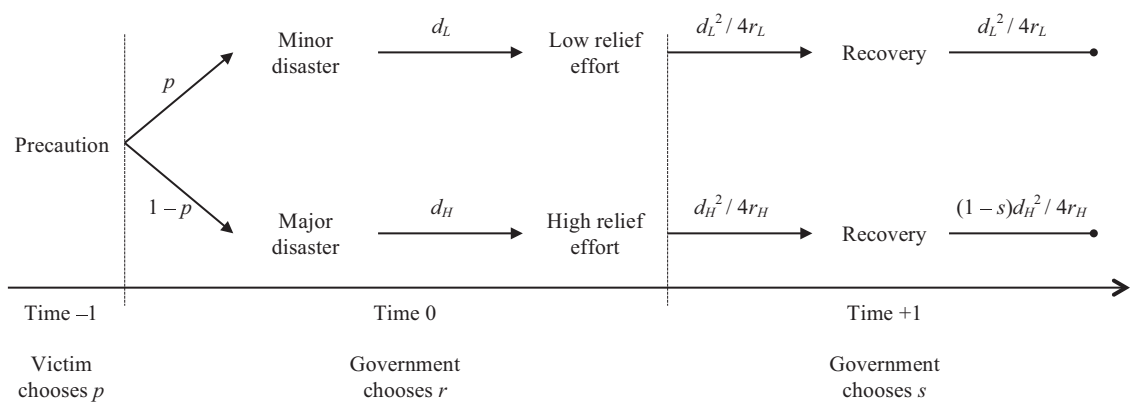

Figure 2. Government Relief.

$d_{L}^{2} / 4 r$; otherwise, if the disaster is major, damages are $d_{H}^{2} / 4 r$. This formulation captures the idea that investing $r \geq 0$ in relief immediately after the disaster reduces the magnitude of damages. In addition, it captures the fact that investments exhibit decreasing marginal productivity: that is, the initial investments reduce the losses by a larger extent than successive investments. One could of course use a much more general formulation that does not assume a specific functional form but has the property of inducing decreasing marginal reduction in the magnitude of the losses. However, using a simple, specific, functional form has the advantage of providing easy-to-interpret results.

If the disaster is minor, the optimal level of relief minimizes the social cost of disasters - that is, damages plus relief effort - and hence solves

$$
\operatorname{Min}_{r}\left[d_{L}^{2} / 4 r+r\right]
$$

To find the level of $r$ that minimizes the cost above we use a standard technique. We calculate the first derivative of the expression above and set it to zero, which gives us the first-order condition. Simplifying the resulting expression, we obtain the values of interest. The first-order condition of the expression above yields that the socially optimal level of relief is

$$
r_{L}^{*}=d_{L} / 2
$$

Similarly, if damages are high, the socially optimal level of relief is

$$
r_{H}^{*}=d_{H} / 2
$$

Note that, as one might have expected, the socially optimal level of relief effort is greater if damages are high, $r_{H}{ }^{*}>r_{L}{ }^{*}$; that is, it is socially optimal to respond more strongly to more destructive disasters. We assume that the government does so. 


\section{Precaution}

At time -1 , the victim chooses a level of precaution $0 \leq p \leq 1$. Precaution has the effect of shifting probability from high to low damages. For instance, seismic retrofitting makes it more likely that an earthquake will result in only minor consequences rather than causing a major disaster. This idea is captured by the assumption that low damages occur with probability $p$ while high damages occur with probability $1-p$, so that by increasing precaution effort $p$ the victim makes it more likely that the disaster will be minor. In order to lower the probability of high damages, the victim bears a cost of precaution equal to $p^{2} / 2$, which exhibits the usual properties of increasing marginal cost of effort. As with $r$ above, this formulation captures initial investments in precaution as more productive than additional investments. Again, the choice of a specific functional form is made for simplicity and allows for explicit results.

From a social point of view, the optimal level of precaution accounts both for damages and for the costs of relief effort taken in each case. That is, the victim should ideally set precaution effort in anticipation of the effects and the costs of relief in both high-damage and low-damage cases (the first two addenda in the expression below) and accounting for the costs of precaution (the third addendum). Thus, the socially optimal level of precaution solves

$$
\operatorname{Min}_{p}\left[p\left(d_{L}^{2} / 4 r_{L}^{*}+r_{L}^{*}\right)+(1-p)\left(d_{H}^{2} / 4 r_{H}^{*}+r_{H}^{*}\right)+p^{2} / 2\right]
$$

After substituting the levels of relief provided by the government, $r_{L}{ }^{*}$ and $r_{H}{ }^{*}$, we can rewrite the social cost minimization problem as

$$
\operatorname{Min}_{p}\left[p d_{L}+(1-p) d_{H}+p^{2} / 2\right]
$$

The first-order condition yields that, given optimal relief effort by the government, the socially optimal level of precaution is

$$
p^{*}=d_{H}-d_{L}
$$

Intuitively, the desirable level of precaution is such that the marginal cost of precaution on the left-hand side of (3) is equal to the marginal benefit of precaution on the right-hand side of (3), as measured by the difference between high and low damages. However, when choosing precaution, victims do not bear the costs of relief directly - as they are most likely spread among the general population through taxation or are partially funded by charitable organizations - and hence they choose a level of precaution that only minimizes the damages. Moreover, if the government pays a portion $s$ of the damages at time +1 , this eventuality will be taken into account while setting precaution. Therefore, the victim's minimization problem does not account for the full costs of relief and damages and hence is different from the social 
cost minimization problem. The expression below only includes the costs of high- and low-damage disasters and the cost of precaution

$$
\operatorname{Min}_{p}\left[p\left(d_{L}^{2} / 4 r_{L}^{*}\right)+(1-p)(1-s)\left(d_{H}^{2} / 4 r_{H}^{*}\right)+p^{2} / 2\right]
$$

After substituting $r_{L}{ }^{*}$ and $r_{H}{ }^{*}$, we can write

$$
\operatorname{Min}_{p}\left[p d_{L} / 2+(1-p)(1-s) d_{H} / 2+p^{2} / 2\right]
$$

The first-order condition yields that, given optimal relief effort, the level of precaution chosen by victims is ${ }^{4}$

$$
p^{\wedge}=\left[(1-s) d_{H}-d_{L}\right] / 2
$$

\section{Results with Government Relief}

The two important expressions that we will compare are (3) and (4). There are two inefficiencies associated with government intervention in disaster management, and both reduce the level of precaution taken by victims below the socially optimal level, so that $p^{\wedge}<p^{*}$. On the one hand, government recovery makes the victim internalize less than the full damages resulting from major disasters and hence dilutes the victim's incentives to invest in precaution. As can be seen from (4), victims set precaution effort while anticipating that they will not bear a portion $s$ of the high damages. On the other hand, government relief efficiently reduces the consequences of disasters, but its costs are not considered by victims. As can be seen from (4) victims bear at most half of the total cost of disasters compared to (3), the other half consisting in the externalized costs of relief.

Proposition 1. Both government recovery and government relief dilute the victim's incentives to take precaution: $p^{\wedge}<p^{*}$.

\section{B. VICTIM'S RELIEF}

In the second scenario, relief effort is set by the representative victim at a general level, irrespective of damages; this is due to the fact that victims do not dispose of sufficient budget and capacity to mobilize the resources that are necessary to optimally respond to each type of disaster. Rather, the victim prepares in advance a one-size-fits-all response (sets aside food supplies to cope with emergencies, for instance). These supplies will typically be excessive in low-damage disasters and insufficient in high-damage ones. In other words, the information about the magnitude of damages cannot be optimally used to tailor the relief response to the specifics of the disaster. This idea is captured by the assumption that the victim chooses relief effort at time -1 (before the disaster) and then applies it at time 0. Figure 3 depicts this 


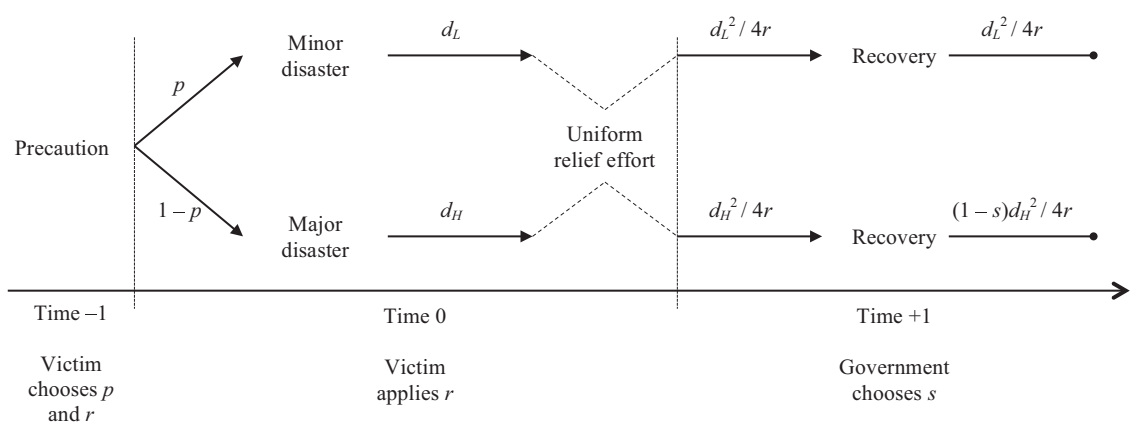

Figure 3. Victims' Relief.

scenario. There are other ways to capture the victims' limited ability to respond to disasters, such as capping the maximum relief effort that the victim is able to apply. Yet, these alternative formulations yield analogous results.

\section{Recovery}

At time +1 , the government pays a portion $0 \leq s \leq 1$ of the damages of major disasters, as before.

\section{Relief and Precaution}

At time 0 , the victim applies relief effort set at time -1 . Since the victim sets both relief and precaution at time -1 , before the disaster, we can analyze them together. Because the victim pays for relief, relief costs now show up in the victims' minimization problem, but, as before, the victim anticipates that the government will pay for a portion of the recovery costs and hence does not fully internalize the damages resulting from major disasters. Hence, the victim's minimization problem is

$$
\operatorname{Min}_{(p, r)}\left[p d_{L}^{2} / 4 r+(1-p)(1-s) d_{H}^{2} / 4 r+r+p^{2} / 2\right]
$$

The first term is the cost of minor disasters; the second term is the cost of major disasters, accounting for the fact that recovery is partially paid by the government; the third term is the cost of relief now borne by the victim; the fourth and last term is the cost of precaution by the victim. The first-order conditions yield levels of precaution and relief such that $t^{5}$

$$
\begin{aligned}
& p^{\wedge \wedge}=\left[(1-s) d_{H}{ }^{2}-d_{L}{ }^{2}\right] / 4 r^{\wedge \wedge}
\end{aligned}
$$

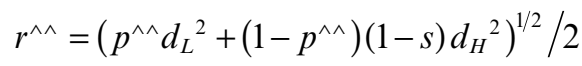




\section{Results with Victims' Relief and Comparison with Government Relief}

Victims' relief is not subject to the same inefficiencies that affect government relief. Unlike with government relief, now the victim bears relief cost, but relief is inefficient because it is applied uniformly to both minor and major disasters. Typically, victims' relief will be too high for minor disasters and too low for major ones precisely because the victim is not capable of tailoring relief effort optimally to the circumstances. These inefficiencies are not due to moral hazard, but rather to the fact that victims have inferior information and more limited resources than the government. This can be seen by comparing (1) and (2) with (6).

Proposition 2. Victims' relief lies in between the socially optimal levels of government relief: $r_{L}{ }^{*}<r^{\wedge}<r_{H}{ }^{*}$.

In addition, since relief is not at its differentiated socially optimal levels, the victim compensates relief inefficiencies by increasing the level of precaution, as can be seen by comparing (4) with (5). This suggests that when relief is paid for by victims, the traditional moral hazard problem is mitigated, resulting in higher levels of precaution.

Proposition 3. The level of precaution with victims' relief is greater than the level of precaution with government relief: $p^{\wedge}<p^{\wedge}$.

A second inefficiency arises from the fact that the victim does not bear the full cost of major disasters, which further affects the incentives to invest in relief and precaution. Note further that it is not necessarily the case that government recovery reduces both relief and precaution. In fact, a lower level of relief makes precaution more valuable so that the effect of recovery on precaution could be countered by the effect of reduced relief on precaution. Vice versa, lower precaution makes it more important to apply relief effort. The results will depend on the specifics of the case and, more precisely, on the size of $d_{H}$ and $d_{L}$. Summing up, if the government invests more in recovery $s$, either relief or precaution by the victim will fall; sometimes, but not always, both relief and precaution will fall.

Proposition 4. Government recovery dilutes the victims' incentives to invest in relief and/or precaution.

\section{THE DIFFERENT EFFECTS OF GOVERNMENT RELIEF AND GOVERNMENT RECOVERY}

In the previous parts, we have shown that government relief and recovery are similar in that they might dilute the victim's incentives to take precaution ex ante. The intuition is straightforward: if the government provides relief or recovery, victims do not pay the full costs of disasters and hence reduce their precautionary efforts below the socially optimal level. In this sense, government intervention is a substitute for victims' precaution. However, relief and recovery are different in fundamental respects.

First, the dilution of precaution incentives caused by recovery is entirely inefficient, because recovery does not reduce the social cost of accidents but 
only shifts part of the social cost to the taxpayers. Thus, the damages caused by a disaster are unaffected by recovery, and no reduction in precaution should be warranted. In contrast, relief reduces the social cost of accidents, and hence it is optimal to reduce precaution somewhat. The reduction in precaution could be excessive, due to the fact that victims do not bear the full relief costs, but is not entirely inefficient.

The second important difference between government relief and government recovery stems from the fact that while government recovery inefficiently distorts victims' incentives, government relief reduces the costs of recovery, and hence has a positive ex post effect, because it reduces the damages that will have to be paid for either by the victim or by the government. We will expand on these issues in the following section.

\section{A. THE EFFECTS OF RECOVERY ON PRECAUTION}

Substitutability is the basis for the general criticism in law and economics literature, namely, that the availability of solutions ex post might reduce incentives to look for cheaper solutions ex ante. The literature has emphasized that a too generous intervention ex post will affect incentives for precaution. Victims may count on being bailed out ex post by politicians (Epstein 1996; Zeckhauser 1996), and to the extent that political intervention is expected, recovery reduces the incentives of victims to take precautions. Politicians themselves may be more inclined to invest in visible, politically rewarding ex post recovery efforts than in less visible ex ante precautionary measures, the political benefits of which are less clear. Thus, there are political incentives for politicians to substitute recovery for precaution and for victims to free ride on ex post intervention by reducing their ex ante precautionary expenditures (Depoorter 2006).

Shughart $(2006,44)$ nicely describes how recovery can negatively affect precaution (referring to the case of Katrina):

Shifting a large portion of the cost of recovery to the tax payers encourages people to rebuild who would not have chosen to do so if they instead shouldered the full costs themselves. The prospect of receiving federal and state reconstruction assistance after the next hurricane strikes supplies incentives for others to relocate their homes and businesses from inland areas of comparative safety to vulnerable coastal areas.

Equally, Mileti $(1999,137)$ argues that individuals typically underinvest in precautions against hazards: "People typically are unaware of the hazards they face ... and rely heavily on emergency relief when the need arises." These problems, hence, mainly result from inefficient compensation negatively affecting the incentives of victims for precaution; the situation is different as far as relief is concerned.

Reconstruction typically involves repairing infrastructure and is usually undertaken by government and not by individuals. Therefore, whereas 
compensation may negatively affect ex ante incentives for precaution on the part of individuals, this is not necessarily the case for reconstruction. For instance, the fact that the government will reconstruct a destroyed bridge (a public good) ex post will not affect the ex ante incentives of potential victims to take precautions. Yet politicians themselves may prefer to intervene ex post, with extended budgets and under the watchful eye of the media, rather than ex ante, when intervention is not salient and its benefits latent. Moreover, although economists have often stressed the beneficial effects of comprehensive disaster insurance (Kunreuther 1968), politicians are often reluctant to introduce insurance solutions and rather prefer recovery, either in the form of reconstruction or ex post compensation to victims. The literature has indicated many reasons why politicians prefer disaster recovery policy over insurance. One explanation is that there are concentrated benefits (to victims living in hazard-prone areas) and diffuse costs (to taxpayers); another reason for continued federal reliance on disaster relief stems from the extraordinary media coverage that catastrophes typically generate (Moss 2010).

Reconstruction is also criticized for encouraging inefficient location decisions by potential disaster victims. Partly because of the endowment effect (Novemsky and Kahneman 2005; Carmon and Ariely 2000; Thaler 1980), government rebuilding often occurs in previously destroyed hazard-prone areas. Thus, "[m]any economists debated the wisdom of rebuilding New Orleans and strengthening the protections against future flooding, given the inherent riskiness of the Gulf Coast region" (Viscusi 2010, 145). Moreover, automatic reconstruction in the wake of disasters may reinforce cognitive mechanisms that distort the perception of risk (Pidot 2012). In principle, recovery could enhance precaution by providing opportunities to reshape destroyed communities in ways that improve their resilience to future disasters. However, evidence shows "a strong bias on the part of decisionmakers towards maintaining the status quo" (Mileti 1999, 236), and thus, local leaders fail to take advantage of the recovery period to increase precautionary measures. Moreover, local governments will have incentives to maximize development in order to raise tax revenues, whereas they can externalize the costs largely to the federal government paying for recovery (Pidot 2012). This criticism also applies to subsidized insurance schemes, such as the NFIP, which, by providing subsidies for flood insurance, both prevents insurance companies from profitably offering competing policies and "provides incentives for property development in high-risk areas" (Young 2008, 566). Pidot (2012) argues that reconstruction in hazard-prone locations following disasters is largely due to the metaphor of disaster as war. By reconstructing the devastated area, the enemy can be defeated.

A final problem, common to both compensation and reconstruction, is that the feedback effects of precaution on recovery, and vice versa, reinforce each other. Recovery ex post is more necessary, salient, and mediagenic the more vulnerable the disaster victims are ex ante. Thus, on the one hand, the 
availability of recovery reduces incentives for precaution; on the other hand, reduced incentives for precaution make for bigger disasters and therefore attract a larger amount of recovery, which further reduces victims' and governments' incentives to undertake precautionary measures. In sum, the traditional arguments against ex post government intervention after disasters certainly apply as far as recovery (both compensation and reconstruction) are concerned.

\section{B. THE EFFECTS OF RELIEF ON PRECAUTION AND RECOVERY}

The situation is different with respect to the effects of relief on precaution and recovery. Disaster relief encompasses all those measures that must be taken in the immediate aftermath of a disaster. Intervention must be quick and tailored to the situation. Disasters are unusual occurrences, abnormal situations caused by unpredicted natural events or human failures. Information about how best to carry out disaster relief is most readily available ex post, after the disaster has occurred. Ex ante, only limited, very general measures can be taken - through trained rescue teams, evacuation plans, disaster management agencies, and concern control units - to prepare for such events. By contrast, reconstruction efforts, whose costs and modes of execution can be determined ex ante, consist of a series of common steps taken to rebuild and restore the devastated area. Obviously, an ex post intervention is efficient because it relies on information available at the moment, while ex ante planning must be adapted to a host of hypothetical scenarios (Leonard and Howitt 2010). We do not mean to suggest that the emergency response should not involve any planning at all. Some relief actions can be planned in anticipation of a disaster, but the real action takes place ex post.

Clarke (1999) shows that effective planning for relief is virtually impossible, stressing the importance of ex post, ad hoc intervention. He argues, moreover, that planning may include the creation of fantasy documents, which are merely tools to convince the public that experts are in charge and that all is well. Thus, Clarke argues that fantasy documents, as such, may even increase risk by giving people a false sense of security. Planning a reaction to a disaster is therefore only possible to some extent, as relief actions will strongly depend upon the particular nature of the disaster.

But will the government provide optimal relief effort? Relief activities are less affected by the problems of ex post political incentives than recovery efforts. Of course, the problem can still arise, even in the case of immediate emergency relief, that such actions have significant political (electoral) benefits. Depoorter (2006) shows that, post-Katrina, various governments in the United States literally competed to provide immediate relief, while prior to Katrina, there was a lack of investment in Louisiana's zoning regulation and emergency planning. Because of the substantial political benefits of ex post action, the reverse is true as well: there may be an oversupply of ex post relief at the expense of precautionary measures. Yet, excessive relief is less 
problematic than excessive recovery precisely because it is optimal to respond more energetically to major disasters than to minor ones, so that political incentives go in the same direction as socially optimal choices.

\section{Effects of Relief on Precaution}

As relief actually reduces the social cost of disasters, some reduction in precaution is warranted. However, victims might reduce precaution below the socially optimal level because they do not bear the costs of relief effort. Yet, there are reasons to believe that this problem is less serious with relief than with recovery. Relief activities are aimed at the rescue of persons and property, to limit (the probability of) severe damages. Very often, they fall dramatically short of completely removing the possibility of property and personal loss, leaving victims seriously harmed. Some harm, moreoverincluding injury, loss of life, and loss of personal belongings - may be of a noncompensable nature. For these relief activities, moral hazard is less of a problem, as relief does not provide full compensation but merely mitigates further damage. Relief measures are often aimed at saving lives and irreplaceable belongings, often of a nonpecuniary nature. As the law and economics literature has indicated, often there will be no demand for insurance on such irreplaceable items or for nonpecuniary damage (Lindenbergh and Kippersluis 2009; Cook and Graham 1977; Zeckhauser 1973). The inevitable residual losses are likely to provide powerful incentives for victims to avoid over-reliance on disaster recovery.

\section{Effects of Relief on Recovery}

Relief has an obvious beneficial effect on recovery: the more resources are devoted to satisfying the immediate needs of the victims of a disaster, the less need there is for recovery. Moreover, government relief is not necessarily more expensive than victims' relief. Our model shows that it is simply better tailored to the situation. On balance, the total expenditures in relief could be the same with and without government intervention. Even keeping costs constant, government intervention makes relief more efficient.

This implies that more catastrophic events will be met with more energetic responses. Thus, the direct effect of government relief effort is a narrowing of the spread of losses. Major disasters result in less harm (while minor disasters might result in more harm) than with victims' relief. This in turn has two effects on recovery. First, it reduces recovery costs in major disasters and, second, it curbs political incentives to oversupply recovery, hence alleviating the dilution of incentives with ex ante precaution. The latter effect is due to the salience of major disasters in the news. The bigger the scale of harm, the more attention and funds will be drawn to recovery. Hence, applying relief effort and reducing the magnitude of the loss is likely to result in cheaper and less inefficient recovery ex post. 
Although provision of relief can be handled by private actors, local authorities, or nongovernmental organizations (NGOs), there are strong arguments in favor of central coordination of relief efforts. We will examine these in turn.

\section{A. SCALE, SPEED, AND SCOPE}

Disaster relief clearly has a public good character. As a result, private parties may have no incentive to take such measures, and government may be best placed to do so. Second, there may be large economies of scale in immediate disaster relief; whereas long-term restoration (e.g., rebuilding houses) could be handled by private parties, coordinated action by government in providing immediate relief is likely to be cost effective. The scale and suddenness of relief activities may require the quick pooling of immense resources and an effective coordination effort in a short period of time. Both pooling and coordination suggest that relief activities are best managed at a centralized level. In contrast, reconstruction activities can be spread over a longer time period, requiring less pooling and coordination. In the words of Trebilcock and Daniels (2006, 92):

The case for intervention is heightened when government-sponsored infrastructure projects enjoy significant economies of scale, require the exercise of powers of eminent domain to develop the projects, and/or exhibit natural monopoly characteristics. As with many other forms of public infrastructure, this appears to be true of precautions, such as construction of dams, levees, dikes, and other forms of flood works where public involvement would seem likely to yield more socially optimal levels of investment than purely private decision-making.

However, there are also contrary arguments. The dramatic failure of FEMA during the week of, and just after, hurricane Katrina led to some skepticism regarding the need for government intervention in relief activities. Shughart (2011, 529), for example, argues that disaster relief is a poor public good:

The immediate task required of first responders is to supply what are essentially private goods. Rescuing survivors from the rooftops of flooded homes and businesses or digging them out of the rubble are rivalrous activities. Everyone in immediate danger cannot be moved to safety simultaneously; when a rescuecrew is working to locate survivors at one disaster scene, others necessarily must wait their turns.

He therefore doubts that disaster relief is an activity in which the government has a distinct comparative advantage. Moreover, Ahmed and Iqbal (2009) have also shown empirically that an elected government at the local level does not necessarily help to mitigate disaster risks. Only when political decentralization is accompanied by fiscal decentralization can activities at the lowest 
tier of government significantly reduce total deaths. The argument is that greater fiscal responsibility makes a local elected government more responsive to vulnerable people.

\section{B. SECURITY}

One of the important goals of relief measures is to guarantee security. Without security, relief measures may fail altogether, as individuals, fearful of looting or violence, may be hesitant to follow an evacuation order. This problem was one of the reasons for the high death toll after Katrina, where many failed to evacuate after the mandatory evacuation order. As Landy $(2008,188)$ notes:

Undoubtedly, individuals who could have left had strong reasons not to obey the order. They feared looting. They treated the evacuation order as just another case of the government crying wolf. The presence of so many people in the flooded area was the reason so many people died. This act of civil disobedience, far more than any failures on the part of emergency responders, led to the high death toll.

This shows that a primary reason for the government to intervene in relief actions is to guarantee security. If individuals in a disaster area fear looting and increased crime, relief actions may fail, and as the case of Katrina shows, an increased death toll may result.

\section{BALANCING OF RIGHTS}

In aiding one party, the property of another may be damaged or destroyed. In private law, the common law doctrines of state of necessity and selfdefense address similar dilemmas in ordinary situations (see, for instance, Restatement (Second) of Torts $\S \S 63-87,196-97$ ). However, disasters occasion these dilemmas on a large scale, so that government oversight may be required. Two problems may arise. First, individuals may infringe reciprocally (even if justifiably) on each other's rights, creating a potential for violence. Second, disasters create situations in which it is difficult to gather evidence to assess, ex post, whether infringements were legally founded or not; thus, there is a potential for abuse. The state is in the best position to balance and protect individual rights and guarantee order. Moreover, De Geest (2012) argues that it is important to provide the government involved in such tasks with immunity.

\section{CONCLUSIONS}

We have introduced a distinction between three relevant sets of activities that can be undertaken to reduce the probability or magnitude of disasters: 
precaution, relief, and recovery. To the extent that precaution and recovery are substitutes, the prospect of ex post recovery efforts reduces the incentives of potential victims and governments to take precautions; victims can count on government ex post intervention, and politicians prefer making funds available ex post rather than ex ante. Moreover, a lack of ex ante precaution leaves victims more vulnerable to disaster and therefore makes recovery more necessary and salient ex post, reinforcing the effect. In contrast, relief and precaution are complements; thus, relief efforts tend to reduce precautionary efforts less than recovery does. Relief and recovery, on the other hand, are substitutes, so that possibly excessive relief efforts will reduce recovery costs ex post, resulting in relatively small net social costs. Therefore, most of the criticisms of government intervention that we have examined refer to recovery and apply only in a limited way to relief. Thus, while recognizing the problems associated with government recovery efforts, our analysis supports government relief efforts.

Undoubtedly, the literature that was criticizing ex post intervention did not object to the government providing shelter and immediate help in the aftermath of a disaster; however, we showed that one has to carefully distinguish between the different types of ex post intervention, more particularly distinguishing between relief and recovery. The case of hurricane Katrina moreover shows that de facto large amounts of ex post spending go to relief rather than to recovery in the sense of victim compensation. Still, the mere fact that the criticism does apply to compensation and less to relief and reconstruction does not mean that all relief or reconstruction actions are necessarily cost effective. In the aftermath of Katrina, many criticisms were heard in that respect. However, we argued and also showed in the model that those potentially negative consequences of relief, as far as incentives for precaution are concerned, are to a large extent outweighed by the benefits that are generated by relief, which is not the case for recovery.

Several issues that we touched upon undoubtedly merit a more in-depth analysis. We, for example, strongly argue that the government may be best placed to provide relief. However, in some cases, private parties or NGOs intervene in providing relief as well; the optimal division of labor between both surely merits further research. Also, our analysis largely applies to the case of natural disasters. For man-made disasters, an additional complication is created by the fact that incentives would have to be provided to a liable tortfeasor for efficient precautionary measures, and for balancing those precautionary measures with effective relief and recovery. While our general results remain valid, the intervention of the tortfeasor raises questions about the optimal division of labor between the government and the tortfeasor as far as relief and recovery are concerned. The recent case of the disaster with the offshore rig Deepwater Horizon shows that interesting issues arise in that respect as well (such as whether the tortfeasor should equally finance relief efforts), which equally merit further research. Moreover, the brief 
discussion of Katrina also illustrated a general point made in the literature: there will be underinvestment in precaution. To some extent, those underinvestments may lead to the liability of public authorities whereby the question equally arises to what extent public authority liability could provide a remedy to incentivize authorities toward optimal investments in precaution. Those and other related questions can and will undoubtedly be addressed in further research.

\section{NOTES}

1. Insurers in Japan have a differentiated premium system. Depending on whether constructions are of wood or stone (the latter being safer than the former) and whether an earthquake-safe construction technology is chosen, differentiated premiums apply. See Report: Japan 6.

2. The essence of our argument is that it is efficient that the government provides some level of relief in the aftermath of a disaster and that relief effort reduces the costs of precaution (ex ante) and recovery (ex post). The argument is not based on who takes precaution ex ante, and hence holds both if victims take precaution and if the government takes precaution. In the model we focus on victims' precaution: for instance, victims might decide to locate far away from a dam. However, in reality, it is often optimal and it in fact happens that the government takes precaution: the government could build safer dams, for instance. Yet, our argument about relief is even stronger when the government takes precaution. This is because when the government pays for precaution, relief, and recovery, the dilution of incentives that we identify with victim precaution in the model does not occur. Hence the efficiency gains are larger.

3. This assumption does not affect the results. Any finite range of damage indexes $\left[d^{\min }, d^{\max }\right]$ can be mapped onto the unit interval $[0,1]$ by means of a simple linear transformation. In the real world, damages occur along a continuum of possibilities and precautionary effort changes the probability density function of the realization of damages. Considering a simple case with only two damage levels simplifies the analysis while preserving the essential elements of the problem. Note further that $d_{L}$ and $d_{H}$ are simply indexes of the two types of disasters. The realized damages will depend on the relief effort $r$ as explained in the text. Once divided by very small levels of $r$, damages can be larger than unity and possibly very large.

4. Note that $p^{\wedge}=0$ if $s>1-d_{L} / d_{H}$; that is, if the government takes up a very large portion of the recovery costs or if the difference between high and low damages is too narrow.

5. The second-order conditions for $p$ and $r$ and the condition for an internal stationary point to be a maximum are satisfied. In the analysis, we only focus on internal solutions but note that there are ranges of values for the damages that require $p=0$ or $p=1$. Our analysis also applies to these cases.

GIUSEPPE DARI-MATTIACCI is a Professor of Law and Economics at the Amsterdam Center for Law and Economics, University of Amsterdam.

MICHAEL G. FAURe is a Professor of International and Comparative Environmental Law at Maastricht University, and a Professor of Comparative Private Law and Economics at Erasmus School of Law, the Netherlands. 


\section{REFERENCES}

Ahmed, Meheran, and Kazi Iqbal. 2009. Disaster and Decentralisation. Working Paper Series, No 2009-03. Northfield, MN: Carleton College, Department of Economics.

Bruggeman, Veronique. 2010. Compensating Catastrophe Victims: A Comparative Law and Economics Approach. Alphen aan den Rijn, the Netherlands: Kluwer Law International.

Bruggeman, Veronique, Michael Faure, and Myriam Haritz. 2011. "Remodelling Reparation: Changes in the Compensation of Victims of Natural Catastrophes in Belgium and the Netherlands," Disasters 35: 766-88.

Carmon, Ziv, and Dan Ariely. 2000. "Focusing on the Forgone: How Value Can Appear so Different to Buyers and Sellers," Journal of Consumer Research 27: 360-70.

Clarke, Lee. 1999. Mission Improbable: Using Fantasy Documents to Tame Disaster. Chicago: Univ. of Chicago Press.

Coate, Stephen. 1995. "Altruism, the Samaritan's Dilemma, and the Government Transfer Policy," American Economic Review 85: 46-57.

Cook, Philip J., and Daniel A. Graham. 1977. "The Demand for Insurance and Protection: The Case of Irreplaceable Commodities," Quarterly Journal of Economics 91: 143-56.

De Geest, Gerrit. 2012. "Who Should Be Immune from Tort Liability?" Journal of Legal Studies 41: 291-319.

Depoorter, Ben. 2006. "Horizontal Political Externalities: The Supply and Demand of Disaster Management," Duke Law Journal 56: 101-25.

Durant, Isabelle C. 2006. "Belgium." In Financial Compensation for Victims of Catastrophes: A Comparative Legal Approach, edited by Michael Faure and Ton Hartlief, 59-65. Vienna: Springer.

Ellickson, Robert. 1973. "Alternatives to Zoning: Covenants, Nuisance Rules, and Fines as Land Use Controls," University of Chicago Law Review 40: 681-781.

Epstein, Richard. 1996. "Catastrophic Responses to Catastrophic Risks," Journal of Risk and Uncertainty 12: 287-308.

Farber, Daniel A. 2007. "Basic Compensation for Victims of Climate Change," University of Pennsylvania Law Review 155: 1646-56.

Faure, Michael G. 2013. "Towards Effective Compensation for Victims of Natural Catastrophes in Developing Countries." In Regulating Disasters, Climate Change and Environmental Harm: Lessons from the Indonesian Experience, edited by Michael G. Faure and Andri Wibisana, 243-76. Cheltenham, UK: Edward Elgar.

Faure, Michael G., and Jing Liu. 2012. "The Tsunami of March 2011 and the Subsequent Nuclear Incident at Fukushima: Who Compensates the Victims?" William and Mary Environmental Law and Policy Review 37: 129-218.

Garrett, Thomas A., and Russell S. Sobel. 2003. "The Political Economy of FEMA Disaster Payments," Economic Enquiry 31: 496-509.

Garrett, Thomas A., Thomas L. Marsh, and Maria I. Marshall. 2006. "Political Allocation of US Agriculture Disaster Payments in the 1990s," International Review of Law and Economics 26: 143-61.

Gollier, Christian. 2005. "Some Aspects of the Economics of Catastrophe Risk Insurance." In Catastrophic Risks and Insurance, 13-30. Paris: OECD Publishing.

Hinghofer-Szalskay, Dagmar, and Bernhard A. Koch. 2006. "Austria." In Financial Compensation for Victims of Catastrophes: A Comparative Legal Approach, edited by Michael Faure and Ton Hartlief, 12-16. Vienna: Springer.

Houck, Oliver. 2006. "Can we Save New Orleans?" Tulane Environmental Law Journal 19: 31-34. 
Iacobucci, Edward M., Michael J. Trebilcock, and Huma Haider. 2001. Economic Shocks. Defining a Role for Government. Toronto: C. D. Howe Institute.

Kaplow, Louis. 1991. "Incentives and Government Relief for Risk," Journal of Risk and Uncertainty 4: 167-75.

Kleindorfer, Paul, Howard Kunreuther, and Chieh Ou-Yang. 2012. "Single-year and Multi-year Insurance Policies in a Competitive Market," Journal of Risk and Uncertainty 45: 51-78.

Kousky, Carolyn, and Howard Kunreuther. 2013. Addressing Affordability in the National Flood Insurance Program. Working Paper No 2013-12. Philadelphia: Risk Management and Decision Process Center, the Wharton School, Univ. of Pennsylvania. http://opim.wharton.upenn.edu/risk/library/WP2013-12 Affordability-NFIP_CK-HK.pdf (accessed May 5, 2015).

Kunreuther, Howard. 1968. "The Case for Comprehensive Disaster Insurance," Journal of Law and Economics 11: 133-163.

---. 2006. "Has the Time Come for Comprehensive Natural Disaster Insurance?" In On Risk and Disaster: Lessons from Hurricane Katrina, edited by Ronald J. Daniels, Donald F. Kettl, and Howard Kunreuther, 172-202. Philadelphia: Univ. of Pennsylvania Press.

---. 2010a. "Long-Term Contracts for Reducing Losses from Future Catastrophes." In Learning from Catastrophes: Strategies for Reaction and Response, edited by Howard Kunreuther and Michael Useem, 235-48. Saddle River, NJ: Pearson Prentice Hall.

---. 2010b. "Reflections and Guiding Principles for Dealing with Societal Risks." In The Irrational Economist: Making Decisions in a Dangerous World, edited by Erwann Michel-Kerjan and Paul Slovic, 263-74. New York: PublicAffairs.

Kunreuther, Howard, and Erwann Michel-Kerjan. 2005. "Insurability of (mega-) Terrorism Risk: Challenges and Perspectives." In Terrorism Risk Insurance in OECD Countries, 107-48. Paris: OECD Publishing.

Kunreuther, Howard, Erwann Michel-Kerjan, and Nicola Ranger. 2013. "Insuring Future Climate Catastrophes," Climate Change 118: 339-54.

Landy, Marc. 2008. "Mega-disasters and Federalism," Public Administration Review 68: $186-88$.

Leonard, Herman B., and Arnold M. Howitt. 2010. "Acting in Time against Disasters: A Comprehensive Risk-Management Framework." In Learning from Catastrophes: Strategies for Reaction and Response, edited by Howard Kunreuther and Michael Useem, 18-41. Saddle River, NJ: Pearson Prentice Hall.

Lindenbergh, Siewert D., and Peter M. Kippersluis. 2009. "Non-pecuniary Losses." In Tort Law and Economics, edited by Michael Faure, 215-27. Cheltenham, UK: Edward Elgar.

Magnus, Ulrich. 2006. "Germany." In Financial Compensation for Victims of Catastrophes: A Comparative Legal Approach, edited by Michael Faure and Ton Hartlief, 119-44. Vienna: Springer.

Mechler, Reinhard, and Juergen Weichselgartner. 2003. Disaster Loss Financing in Germany - The Case of the Elbe River Floods 2002. Laxenburg, Austria: IIASA. http://webarchive.iiasa.ac.at/Admin/PUB/Documents/IR-03-021.pdf (accessed May 8, 2015).

Michel-Kerjan, Erwann. 2010. "Haven't You Switched to Risk Management 2.0 Yet?" In The Irrational Economist: Making Decisions in a Dangerous World, edited by Erwann Michel-Kerjan and Paul Slovic, 41-46. New York: PublicAffairs.

Mileti, Dennis S. 1999. Disasters by Design: A Reassessment of Natural Hazards in the United States. Washington, DC: Joseph Henry Press.

Monti, Alberto, and Filippo A. Chiaves. 2006. "Italy." In Financial Compensation for Victims of Catastrophes: A Comparative Legal Approach, edited by Michael Faure and Ton Hartlief, 145-94. Vienna: Springer. 
Moss, David A. 2010. "The Peculiar Politics of American Disaster Policy: How Television Has Changed Federal Relief." In The Irrational Economist: Making Decisions in a Dangerous World, edited by Erwann Michel-Kerjan and Paul Slovic, 151-60. New York: PublicAffairs Books.

Novemsky, Nathan, and Daniel Kahneman. 2005. "The Boundaries of Loss Aversion," Journal of Marketing Research 42: 119-28.

Noy, Ilan. 2009. "The Macroeconomic Consequences of Disasters," Journal of Development Economics 88: 221-31.

O'Keefe, Phil, Ken Westgate, and Ben Wisner. 1976. "Taking the Naturalness out of Natural Disasters," Nature 260: 566-67.

Paudel, Youbaraj. 2012. "A Comparative Study of Public-Private Catastrophe Insurance Sytems: Lessons from Current Practices," The Geneva Papers on Risk and Insurance, Issues and Practice 37: 257-85.

Pidot, Justin. 2012. Deconstructing Disaster. Working Paper No 12-43. Denver, CO: Sturm College of Law, Univ. of Denver.

Priest, George. 1996. "The Government, the Market and the Problem of Catastrophic Loss," Journal of Risk and Uncertainty 12: 219-37.

Raschky, Paul A., and Hannelore Weck-Hannemann. 2007. "Charity Hazard-A Real Hazard to Natural Disaster Insurance?" Environmental Hazards 7: 32129.

Schwarze, Reimund, Manijeh Schwindt, Gert G. Wagner, and Hannelore WeckHannemann. 2012. Ökonomische Strategien des NaturengefahrenmanagementsKonzepte, Erfahrungen und Herausforderungen [Economic Strategies for the Management of the Perils of Nature-Concepts, Experiences and Challenges]. Innsbruck, Austria: Innsbruck Univ. Press.

Shavell, Steven. 1983. "Tort in Which Victim and Injurer Act Sequentially," Journal of Law and Economics 26: 589-612.

Shughart, William F. 2006. "Katrinanomics: The Politics and Economics of Disaster Relief," Public Choice 127: 31-53.

---. 2011. "Disaster Relief as Bad Public Policy," Independent Review 15: 529-31.

Sugarman, Stephen D. 2007. "Roles of Government in Compensating Disaster Victims," In: Issues Legal Scholarship 6: 1-33.

Sun, Lisa Grow. 2011a. "Disaster Mythology and the Law," Cornell Law Review 96: $1131-1208$.

---. 2011b. "Smart Growth in Dumb Places: Sustainability, Disaster, and the Future of the American City," Brigham Young University Law Review 6: 2157-2202.

Thaler, Richard. 1980. "Towards a Positive Theory of Consumer Choice," Journal of Economic Behavior and Organization 1: 39-60.

Trebilcock, Michael J., and Ronald J. Daniels. 2006. "Rationales and Instruments for Government Intervention." In On Risk and Disaster: Lessons from Hurricane Katrina, edited by Ronald J. Daniels, Donald F. Kettl, and Howard Kunreuther, 89-107. Philadelphia: Univ. of Pennsylvania Press.

Van Asseldonk, Marcel A. P. M., Miranda P. M. Meuwissen, and Ruud B. M. Huirne. 2002. "Belief in Disaster Relief and the Demand for a Public-Private Insurance Program," Review of Agricultural Economics 24: 196-207.

Van den Bergh, Roger, and Michael G. Faure. 2006. "Compulsory Insurance of Loss to Property Caused by Natural Disasters: Competition or Solidarity?" World Competition 29: 25-54.

Van Langendonck, Jozef. 2007. "International Social Insurance for Natural Disasters?" In Shifts in Compensation between Private and Public Systems, edited by Willem H. van Boom and Michael Faure, 183-97. Vienna: Springer.

Viscusi, Kip W. 2010. "The Hold-Up Problem: Why It Is Urgent to Rethink the Economics of Disaster Insurance Protection." In The Irrational Economist: Making 
Decisions in A Dangerous World, edited by Erwann Michel-Kerjan and Paul Slovic, 142-48. New York: PublicAffairs.

Waugh Jr., William L. 2005. "The Disaster that Was Katrina," Natural Hazards Observer 30. http://www.colorado.edu/hazards/o/archives/2005/nov05/nov05d1. html (accessed May 8, 2015).

Wittman, Donald. 1981. "Optimal Pricing of Sequential Input: Last Clear Chance, Mitigation of Damages and Related Doctrines in the Law," Journal of Legal Studies 10: 65-91.

Young, Andrew T. 2008. "Replacing Incomplete Markets with a Complete Mess: Katrina and the NFIP," International Journal of Social Economics 35: 56168.

Zeckhauser, Richard. 1973. "Coverage for Catastrophic Illness," Public Policy 21: 149-72.

---. 1996. "The Economics of Catastrophes," Journal of Risk and Uncertainty 12: $113-40$.

\section{REPORTS}

Report: Japan. Japan, Earthquake Reinsurance, Annual Report 2010-Introduction to Earthquake Reinsurance in Japan. http://www.nihonjishin.co.jp/disclosure/ 2010/en_disclosure.pdf (accessed February 26, 2015).

Report: Disaster Evacuation. Cong Bea, Research Serve; Disaster Evacuation and Displacement Policy: Issues for Congress 2005. http://www.au.af.mil/au/awc/ awcgate/crs/rsz235pdf (accessed February 27, 2015).

Report: Progress Made. Office of the FED. Coordinator for Gulf Coast Rebuilding, Department of Homeland Security, Progress Made: A 6-month Update on Hurricane Relief, Recovery and Rebuilding 2006. http://disability.law.uiowa.edu/ dpn_hi/90.pdf (accessed May 8, 2015).

Report: A Failure of Initiative. US House of Representatives, A Failure of Initiative. Final Report of the Select Bipartisan Committee to Investigate the Preparation for and Response to Hurricane Katrina 2006, Washington, DC: http://www.nola.com/ katrina/pdf/mainreport.pdf (accessed February 27, 2015).

Report: Lessons Learned. White House, the Federal Response to Hurricane Katrina. Lessons Learned 2006, Washington, DC. http://www.floods.org/PDF/Katrina_ Lessons_Learned_0206.pdf (accessed February 27, 2015).

Report: A Performance Review. Department of Homeland Security, A Performance Review of FEMA's Disaster Management Activities in Response to Hurricane Katrina 2006. http://www.oig.dhs.gov/assets/Mgmt/OIG_06-32_Mar06.pdf (accessed February 26, 2015).

Report: A Nation Still Unprepared. Report of the Senate Committee on Homeland Security and Governmental Affairs, Hurricane Katrina: A Nation Still Unprepared, Executive Summary 2006. http://www.gpo.gov/fdsys/pkg/CRPT-109srpt 322/pdf/CRPT-109srpt322.pdf (accessed February 27, 2015).

\section{APPENDIX: PROOFS}

Proof of Proposition 1. We have $p^{\wedge}=\left(s d_{H}-d_{L}\right) / 2<d_{H}-d_{L}=p^{*}$. Q.E.D.

Proof of Proposition 2. The result follows from the fact that $d_{L}^{2}<p^{\wedge} d_{L}^{2}+\left(1-p^{\wedge \wedge}\right) d_{H}^{2}$ $<d_{H}^{2}$. Q.E.D. 
Proof of Proposition 3. The result follows from the fact that Proposition 2 implies $d_{H}^{2}$ $/ 4 r^{\wedge \wedge}>d_{H}^{2} / 4 r_{H}{ }^{*}$ and $d_{L}^{2} / 4 r^{\wedge \wedge}<d_{L}^{2} / 4 r_{L}{ }^{*}$. Thus, we have $p^{\wedge \wedge}=(1-s) d_{H}{ }^{2} / 4 r^{\wedge \wedge}-$ $d_{L}^{2} / 4 r^{\wedge}>(1-s) d_{H}^{2} / 4 r_{H}^{*}-d_{L}^{2} / 4 r_{L}^{*}=p^{\wedge}$. Q.E.D.

Proof of Proposition 4. Increasing $s$ reduces $p^{\wedge \wedge}$ for any level of $r^{\wedge}$ and, likewise, it reduces $r^{\wedge \wedge}$ for any level of $p^{\wedge}$. Since from the implicit definitions given in the text $p^{\wedge}$ decreases in $r^{\wedge}$ and $r^{\wedge \wedge}$ decreases in $p^{\wedge}$, graphical inspection shows that either $p^{\wedge \wedge}$ or $r^{\wedge \wedge}$ or both decrease as $s$ increases. Q.E.D.

The Model with Government Precaution. The government could take precaution in order to reduce the probability of disasters. Crucially, government precaution is observable to victims and hence the choice of precaution by the government and the victim can be thought of as a sequential game, where the government sets the precaution level at time -2 , before the victim acts. To model government precaution we can think of the probability of disasters as $P(q, p)$, that is as a function of the precautionary effort of the victim $p$ and of that of the government $q$. Since $q$ is observable to the victim at time -1 , the probability of disasters is, after government precaution has been exerted, uniquely determined by the victim's precaution. For any level of government precaution $q$ there will be a subgame starting at time -1 , which has the characteristics of our model and yields analogous results. Therefore, we can consider government precaution as a background variable and focus on the variables of interest; all our results will be essentially preserved. Studying specifically the optimal mix of government and victim precaution is a standard problem in models of torts with two actors acting sequentially and its characteristics are well understood (see for instance Shavell 1983; Wittman 1981). 